\title{
Russian scientists face long fight for justice
}

\section{Bryon MacWilliams, Moscow}

Valentin Danilov is smoking a pipe and drinking black tea from mug that says, in Russian, "Don't touch me". On the mug, a black-and-white drawing of a thumb, pressing downwards, is surrounded by a red circle with a line through it.

In Danilov's case, such pleas are too late. A physicist at Krasnoyarsk State Technical University in Siberia, he was held in custody for 19 months after his arrest in 2001 for allegedly supplying a classified satellitetechnology device to a Chinese company. Last week, his case continued its slow progress through the Russian legal system when the Supreme Court ruled that prosecutors should be given no more time to collect evidence, and that a lower court should reach a decision on the charges.

But no deadline has been set for that decision. The cases of several other scientists also remain unresolved. All date from between 1997 and 2002, when the FSB - the main successor to the Soviet KGB - accused around a dozen people, mainly scientists, of spying. With pressure from the Russian Academy of Sciences appearing to have little effect, human-rights campaigners are trying to increase awareness of what they regard as the persecution of researchers. "It has become fashionable to arrest scientists," Lyudmila Alexeyeva, head of the Moscow Helsinki Group, a human-rights organization, told a press conference in Moscow last week.

Danilov, like the other scientists under threat, has the support of his peers. His device is used to test the effect of electromagnetic activity on satellites, but the FSB believed that

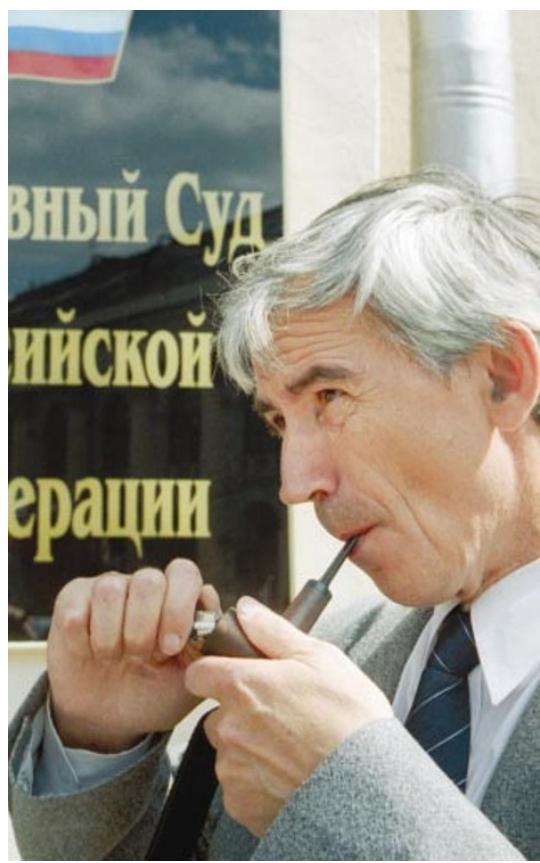

From Russia with love? Valentin Danilov is charged with passing technology to China.

it could help China to develop spacecraft that would threaten Russia's security, although the agency did not say how. But in a letter to a Krasnoyarsk court, sent shortly after Danilov's arrest, 20 Russian scientists pointed out that details of the technology have already been published in scientific journals.

Other scientists have faced similar accusations. Vladimir Shchurov, who heads an acoustics laboratory at the Pacific Oceano- graphic Institute in Vladivostok, was detained by customs officials in 1999 after attempting to deliver an underwater acoustic device to Harbin Engineering University in China. The FSB alleges that the device can be used for military purposes, such as tracking Russian submarines. The academy has written to the court handling the case to affirm that the technology was unclassified. Shchurov's trial is scheduled to begin this week.

Alexeyeva claims that Russian scientists have been an easy target because they collaborate with foreign companies and academic organizations. This, she argues, allows the FSB to accuse them of spying, in the hope that the publicity will deter any researchers who are considering selling classified information from doing so. The FSB had not responded to questions faxed to its offices in Moscow as Nature went to press.

None of the scientists has yet been convicted of spying, however, and some have had their cases dismissed. Last week, charges were dropped against Vladimir Soifer, an ecologist at the Pacific Oceanographic Institute accused of handling classified documents about radioactive pollution from an accident involving a nuclear submarine in Chazhma Bay, near Vladivostok, in 1985. Nature has obtained a copy of a letter sent to Soifer on 18 July, in which V.A. Zhilyaev, a lieutenant general in the FSB, apologizes for the accusations.

Despite the pending case, Danilov says the stigma of being charged has not affected his personal or professional life. Some colleagues even provided financial assistance to his wife while he was imprisoned. "I walk with my head held high," he says.

\section{Anger grows over plan to uproot Indian crop institute}

\section{K. S. Jayaraman, New Delhi}

A row is brewing over plans to relocate the International Crops Research Institute for the Semi-Arid Tropics (ICRISAT), currently based in the Indian state of Andhra Pradesh. Plans to move the centre - one of a global network of 16 Future Harvest centres dedicated to food security and environmental issues - have angered staff and scientists across India, who fear that this will disrupt its research projects.

The proposal came in a report released earlier this month from an independent five-member panel set up by the Washington-based Consultative Group on International Agricultural Research (CGIAR), which runs the Future Harvest centres. The panel said that ICRISAT's outstations in Kenya, Niger and Zimbabwe need strengthening, and that the best way to

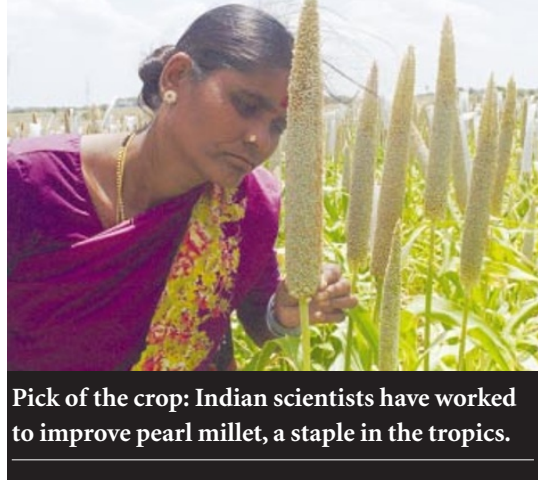

do this is to relocate the institute to Africa.

ICRISAT, which carries out research on crops that are important to the arid regions of Africa and India, such as millet and groundnut, has claimed some notable successes, such as trebling chickpea yields by introducing new varieties. But the panel concluded that its research would have more impact if it were based in Africa.

Budget cuts forced the loss of some 200 positions at ICRISAT last year, but it could be spared further job losses, as the panel concluded that the institute's programme to identify beneficial genes and improve crops through conventional breeding and genetic modification should still be based in India.

The institute will respond to the relocation plan when its board meets in September. "This recommendation is unfortunate," says Raj Paroda, director of the CGIAR programme for central Asia and the Caucasus. He adds that it would adversely affect the growth and development of the institute, as India has stronger national research organizations than Africa. www.icrisat.org 